\title{
Percy Shelley and the Tragedies of Lacanian Psychoanalysis
}

Ben Hewitt*

School of English, University of St Andrews, St Andrews, UK

*bh48@st-andrews.ac.uk

[This is an Accepted Manuscript of an article, accepted for publication on 16.02.2018 by Taylor \& Francis Group in European Romantic Review.]

\begin{abstract}
This essay offers some new perspectives on affinities between the writing and thought of Percy Shelley and Jacques Lacan, focusing on aspects of Lacanian psychoanalysis sometimes identified as "tragic": especially its notions of the divided subject, and of that subject's alienation by language. It first explores parallels between these notions and Shelley's representations of language in Julian and Maddalo. Developing this, by engaging with deconstructive and psychoanalytic approaches to history and language in "The Triumph of Life," it then highlights how Shelley and Lacan each seem to endorse a similar pessimism, a tragic perspective on our efforts to achieve self-understanding, and on human knowledge and potential more widely. Drawing on Fredric Jameson's reflections on Marxism and psychoanalysis, and on his interpretation of Lacan's concept of the "Real," the essay then concludes by bringing Shelley and Lacan into a more positive, politically energizing encounter with one another, via a reading of Prometheus Unbound.
\end{abstract}

Paul Fry's suggestion, in 1979, that Shelley's poetry and prose contain a "Lacanian psycholinguistics in embryo" (451) has seen follow in its wake a number of interpretations of Shelley drawing on Lacanian ideas. Understandably, given the nature of Lacan's theories and 
of the popular currency they have enjoyed in literary studies, the majority of these have in their various ways focused on language and the construction of subjectivity and identity in Shelley's works. Certain of these works share much, arguably on the level of form as well as thematically, with the well-rehearsed, basic Lacanian narrative of the foundation of the individual subject upon "lack": a process of alienation from a pre-verbal, in Lacan's terms Imaginary sense of plenitude and oneness, set in motion by the "shattering of the Innenwelt to Umwelt circle" in the Hegelian "drama" of the mirror stage (Lacan Écrits 6), ending in our initiation into the Symbolic order - the order of language and laws, into which we must all enter, and where we live of necessity with our impossible desire for an inaccessible Other. In his influential study of Shelley's Process, Jerrold Hogle suggests as much, when he writes that "There is simply no construction of an identifiable self in Shelley without a specific counterpart (a person or environment or symbolic order) helping to form that self's structure and possibilities in a mirror" (98). Barbara Charlesworth Gelpi agrees, finding in Shelley's poems "a subjectivity haunted by / mirroring Other(s) who have the character of specters," and stating that "This shared epistemology, along with shared fascination in the links between subjectivity and language, makes Lacanian theory particularly applicable to Shelley's work" (x). As Fry hinted, Lacanian analysis of Shelley can work well in large part because he and Lacan share some of these fundamental concerns with identity, with the process of its construction out of experiences of difference and otherness, and of the role of language in this process, which, as we will see, Shelley represents at times as enslaving and alienating, and as potentially liberating. It is Lacan's approaches to these subjects and concepts that have led some to characterize his thought as "tragic." Indeed, Lacan himself suggested the aptness of this term, with its weight of literary-cultural meaning and significance, to describe his theories: for instance, in the final part of his seminar on The Ethics of Psychoanalysis, entitled "The Tragic Dimension of Psychoanalytic Experience," in which he discusses certain 
premises and assumptions of psychoanalytic theory and practice, by way of an interpretation of Sophocles' Antigone and Oedipus. With reference to this seminar and to other of Lacan's writings, in the first and second sections of the essay, I explore some of Shelley's works with respect to what Sean Homer has called "the tragedy of [Lacanian] psychoanalysis": the difficult confrontation it compels us to enter into, with the notion of a human "subject [that] is inherently divided and can never be satisfied" (104). The first section reads Julian and Maddalo in relation to an aspect of this tragic vision to which Fredric Jameson draws particular attention, Lacan's emphasis on our "unavoidable alienation by language" (Jameson Ideologies 91). The second section then engages with Paul de Man's deconstructive, and Joel Faflak's psychoanalytic approaches to history and language in "The Triumph of Life," to show how Shelley and Lacan each seem to endorse a similar pessimism, a tragic perspective on our efforts to achieve self-understanding, and on human knowledge and potential more widely, which haunts certain of their writings, including these poems by Shelley. In examining this, I hope to suggest some ways in which such intersections between Shelley and Lacan might provide the opportunity for some immanent critical reflections upon the ideas of both, highlighting problems and contradictions in the thought of each, but also pointing, speculatively, to some ways beyond them. Jameson's thinking about Lacan will be important to this (as he is for my analyses generally), especially his interpretation of Lacan's concept of the "Real." This will help us to make connections between some of these more pessimistic and negative, "tragic" aspects of Shelley's and Lacan's thought, in terms of which they can fruitfully be compared, and a different view of their shared concerns, especially of the political implications of their ideas and writings. The final section of the essay provides one such view, bringing Shelley and Lacan into a more positive, politically energizing encounter with one another, via a reading of Prometheus Unbound. 


\section{Tragedy and language in Julian and Maddalo}

Julian and Maddalo, I would suggest, is structured at once as a form of, and as a critical reflection upon, its own status as a tragedy of proto-Lacanian dimensions — and as an exploration in particular of our alienation by the language we must come to inhabit in order to realize ourselves as subjects. Contrasting his own approach with Freud's, Lacan states that "Psychoanalysis should be the study of language inhabited by the subject. From the Freudian point of view man is the subject captured and tortured by language" (Psychoses 243). In Julian and the Maniac, Shelley creates two characters whose relationships to language bear striking resemblances to these Lacanian and Freudian positions, the Maniac's utterances in particular foregrounding his sense of alienation and imprisonment by language. We see this most clearly in the Maniac's struggles with "words":

"How vain

Are words! I thought never to speak again, Not even in secret, - not to my own heartBut from my lips the unwilling accents start And from my pen the words flow as I write, Dazzling my eyes with scalding tears . . . my sight Is dim to see that charactered in vain On this unfeeling leaf which burns the brain And eats into it ... Blotting all things fair And wise and good which time had written there. (472-81)

The Maniac's “thought" never to speak again, not even to his own heart- to refuse language itself, written and spoken communication, even that of his own personal, interior dialogueis akin to a wish to renounce one's very subjectivity, and he thus appears here as a kind of Romantic-Lacanian Ivan Karamazov, contemplating handing back his ticket to Lacan's Symbolic order. This is, however, an impossible desire, in Lacanian terms: it is a wish effectively to become psychotic, a becoming we cannot set in motion for ourselves, even if we wanted to. Such psychosis is caused, for Lacan, by what he calls a "foreclosure" (Verwerfung) of castration, of "the paternal metaphor," in the subject, a foreclosure which is "primordial" (Écrits 210), preceding Symbolic integration, rooted way back in the formation 
of the unconscious. Rejecting language in the Maniac's way would mean, in part, consciously setting in motion the situation in which, "By rejecting the psychic split from the (m)Other" essential to the subject's Symbolic ordering, "the psychotic personality retains a sense of selftotality: a lack of lack" (Ragland-Sullivan 156), a state in which this personality therefore lacks desire itself, is self-enclosed, needs and wants for nothing external to itself. Thus a "gain of psychosis," as Ellie Ragland-Sullivan puts it, might be that the subject is able to deny "the 'truth' of the human condition" (265) — a tragic truth, that the experience of such lack, and of the ever-renewing, impossible desire to overcome it, are basic conditions of the subject's formation. The Maniac seems to long for such a "gain," but cannot achieve it, and thus he experiences something more similar to the tragedy of psychoanalysis — of the divided subject and its alienation by the very language it needs to communicate with others - than to madness. Reflecting further on psychosis, Lacan claimed that "If the neurotic inhabits language, the psychotic is inhabited, possessed, by language" (Psychoses 250). The Maniac is not (quite) "psychotic" in Lacan's understanding of this condition, though he clearly does think of himself as "possessed," as well as "captured and tortured" by the language he is compelled to think, speak and write. The very fact that he can think, and articulate his problem, places him in a kind of limbo, this side of madness. He is not in control of the string of signifiers that thrust themselves upon him—-he certainly is presented to us as lacking Julian's urbane facility with them—but neither is he completely "inhabited" by them: his grip on reality, and on the language that orders his relationship to it, seems easily sufficient to allow him to describe the condition he finds himself in to Julian. This is an important part of the irony of this section of the poem, in which the Maniac apparently suffers much more from his imprisonment by "words," than from his physical confinement, amongst the inarticulate "clap of tortured hands, / Fierce yells and howlings" (215-16) of the other inmates. We are asked to imagine that the language in which the Maniac expresses the violence, futility and 
oppressiveness he associates with "words" is sophisticated and insightful, especially contrasted with these "Moans" and "shrieks" (218) surrounding him in the madhouse. It is thus comparable to the language of Julian himself, through whom it is filtered, and who presumably has ordered the "wild language" of the Maniac's "grief" into language, "Such as in measure were called poetry" (541-42) — the words of the poem, which Julian writes. This poetic rendering may better express what was vital in the Maniac's utterance-what so moves Julian and Maddalo about it — focusing its wildness into a form that renders it accessible to us; or perhaps Julian's metric, rhymed civilizing of this utterance leaves us out of touch with its original, less ordered but more immediate, organic forcefulness. We cannot know, and this is one of the potential failures of communication that Julian's writing of the poem risks, emphasised by his refusal to relate the full story of the Maniac and the "Lady" to "the cold world"— to us—at the poem's ending.

In contrast with the Maniac, Julian is shown to occupy something akin to Lacan's "neurotic" position: he is someone who "inhabits" language all too well, presumably wishing to use it in the cause of the reform he seeks; and who, confronted somewhat traumatically with its limits by the Maniac, now more anxiously inhabits "this earth, / Where there is little of transcendent worth" (590-91), his final inarticulacy hinting at the effects of this encounter upon his sense of the value of his own linguistic, narrative and poetic prowess. We must also remember that, as Julian is the poem's sole narrator, we are imagining him recounting the Maniac's (and everyone else's) words, and so there are levels of irony to consider. Shelley makes us aware of the potential for the Utopia-talking Julian, whose rhetorical capacity and flare for the descriptive and conceptual is foregrounded, to slip over into a similar state: Maddalo first refers to the Maniac as "one like you [Julian] / Who to this city came some months ago," who "is now gone mad" (195-98). This equivalence is supported by Kelvin Everest's important reading of the poem, in which he observes that the Maniac's "passionate 
restatement of Julian's radical creed," which Julian has expressed earlier in the poem, is itself a "failure of communication," showing up how "Julian's own ideals are not mediated for his society," consigning them finally "to an inarticulate limbo, like the madhouse" itself (678). With reference to Everest, William Keach has suggested that the Maniac's speech can be read as "language that wants to function as sublime emotional music, and only sporadically exists as intelligible social and historical discourse." For Keach, in representing this, Shelley is “confronting, not just idealizing or sentimentalizing, an impulse in his own writing [toward such a language] that for many readers, then as now, threatens or limits communication" (90). Julian and Maddalo thus turns upon a confrontation between the "social and historical discourse" that Shelley knows thinkers like Julian and himself must participate in, and the desire to escape it, into a "sublime" language of sheer immediacy, seemingly ideal, but which may in fact be solipsistic and so antithetical to the social and political causes it wants to support. (As we will see, some critics find the lyrical Act 4 of Prometheus Unbound problematic for similar reasons). Monika Lee observes, in the Maniac's discourse, an "idealism and search for an utterance that transcends the boundaries of the linguistic medium" (qtd. in Weisman 413), which Lee sees as an instance of Shelley's engagement with Rousseau, inspired by Julie especially. The Maniac's soliloquy compares also with some of the gloomier reflections of the Discourse on the Origin and the Foundations of Inequality Among Men (second Discourse) — which we know Shelley had read, from his reference to it in the notes to Queen Mab (1813) — for example, when Rousseau writes:

I ask: has anyone ever heard of a savage who was living in liberty ever dreaming of complaining about his life and of killing himself? ... On the other hand, nothing would have been so miserable as savage man, dazzled by enlightenment, tormented by passions, and reasoning about a state different from his own. (60)

The Maniac, of course, has never been "savage": he is a highly cultivated individual whose life has descended into what his society deems madness. But his desire to escape from "words" is also a desire for something like Rousseau's somewhat idealized, pre-civilized 
state. His longing to be somehow outside language is also a wish to be outside the social order in part responsible for wrecking his idealism, leading to his being rendered essentially a prisoner in the madhouse.

Jameson's analysis of Lacan helps to accentuate the political resonances of this, and so to place Julian and Maddalo as a poem looking at once back to Rousseau and on toward Lacan. Jameson connects the Symbolic order explicitly with Rousseau, "for whom ... the social order in all its repressiveness is intimately linked with the emergence of language itself." Lacan is comparable to Rousseau here because any "Utopian" possibilities are cut off in Lacanian thought "by the palpable impossibility of returning to an archaic, pre-verbal stage of the psyche itself," such as that imagined, if not defined or closely analysed, in the second Discourse. Rousseau's account of our entry into a “civilized" social order and Lacan's of our entry into the Symbolic order-the order of laws and social structures, as well as of language — both emphasise how these entries entail elements of violence and repression, the "tragic" element in the thought of each (Jameson Ideologies 91). The Maniac knows this and experiences its effects viscerally, expressed with force and psychological aptness as words burning the impossibility of his ever escaping them onto his brain. It is as if the Maniac experiences what Maud Ellman, referring to Lacan's conception, calls language as “a sacrificial order which exacts its pound of flesh" (19-20). The division and alienation necessary to entering the Symbolic order is nothing less than the price of sanity in Lacan. This sanity, like tragedy, requires a sacrifice, which the Maniac seems to regret having made, and thus the Maniac's tragedy is, in an important sense, his sanity. Hopefully it is clear this does not mean that psychosis is to be understood as an ideal state, any more than Rousseau's "savage" state ought to be thought of as such. Rather, it expresses how the Maniac has come to experience subjectivity (especially its foundation upon language) as tragedy: the nature of subjectivity presents itself to him as a Lacanian tragic bind, an imprisonment between what 
have for him become two equally untenable states. This is the tragic lesson Lacan might teach, of the divided subject and its impossible desires - a lesson which, it seems, Shelley's Maniac has learned. What effect it has had on Julian remains uncertain. The result is that Julian and Maddalo confronts us with an apparently pessimistic, even nihilistic view of language and its relationship to the psyche and the social order, which can seem definitive and insurmountable, suggesting in the poem a tragic limit to Julian's utopian hopes.

\section{Tragedy and history in "The Triumph of Life"}

For Jameson, this tragic tendency suggests a political proximity between Lacan's thought and the "implicit conservatism of the classical structuralist paradigm," with its "anti-Utopian" tendencies (Ideologies 100), a feature of structuralism Jameson first explored in The PrisonHouse of Language. Following the lead of Paul Ricoeur's Le Conflit des interpretations, Jameson proposed that a key problem for structuralism is that "it remains a prisoner" to "the dilemmas of Kantian critical philosophy," staging, in its conception of the split between signifier and signified, "essentially a replay of the Kantian dilemma of the unknowability of the thing-in-itself." Although it can be argued that, strictly, the "thing-in-itself" does not exist for structuralism - there is no extra-linguistic order of things to which the system of linguistic signs refers, only the system itself — the problem remains: "this position merely displaces the problem from Kant to his successors in German objective idealism [e.g. Fichte] without solving it" (Jameson Prison-House 109-10). Major figures in the development of structuralism, such as Lévi-Strauss, Barthes and Althusser, all influences upon Lacan, cannot help presupposing, "beyond the sign-system itself, some kind of ultimate reality," like Kant's noumenal realm, “which, whether knowable or not, serves as its most distant object of reference" (Prison-House 214). And as Tom Eyers reminds us, it has become a common assumption that Lacan is "a thinker ultimately beholden, if only implicitly, to an idealist view 
of language, defined as delimiting all that is accessible to the subject" (37). This was first articulated in deconstructionist fashion, in Nancy and Lacoue-Labarthe's essay The Title of the Letter, to which we will return later. Shelley has also been subject to many deconstructive treatments, which tend to find in his poetry various deconstructions of such an idealist view. The most influential is Paul de Man's essay on "The Triumph of Life," "Shelley Disfigured," which can be connected with a psychoanalytic approach to the poem in some interesting ways. De Man's reading is, of course, very well-known and has been exhaustively discussed, but for reasons which should soon become apparent, it is worth briefly rehearsing one of its main cruxes, its analysis of Shelley's representation of Rousseau. In these lines of the poem (394-410) — in which Rousseau asks the "shape all light" to "Shew whence I came, and where I am, and why," and receives a "new Vision" not wholly answering his questions — de Man focuses on the figural representation of the psychic change Rousseau describes this encounter as working upon him. "The scene dramatizes a failure to satisfy a desire for self-knowledge," de Man writes, in which Rousseau "undergoes instead a metamorphosis in which his brain, the center of his consciousness, is transformed ... [This is] not an act performed by the brain, but the brain being acted upon by something else" (99). Comparing as Rousseau does the "erasure" of deer tracks upon the sand with the change in his own brain, onto which, in terms of this metaphor, the unsatisfactory "Vision" is then marked, de Man suggests that such “erasure or effacement," represented also as the disfigurement of Rousseau's face ("Triumph" 182-88), is the essence of the poem: "This trajectory from erased self-knowledge to disfiguration is the trajectory of The Triumph of Life" (100), a poem that unravels the narrator's and Rousseau's “quests" after knowledge by revealing their reliance upon linguistic processes always prone to disfiguration, sliding interminably into forms of regression and repetition. De Man thus reads the several questions posed by the narratorwhat is the parade of figures he sees before him, how did Rousseau's "course begin ... and 
why?", what is the nature of the "Shape all light" ("Triumph" 297, 352)—creating a situation in which question is answered by question "in infinite regress," establishing a "movement of effacing and of forgetting [which] becomes prominent in the text and dispels any illusion of dialectical progress or regress" that might result from the series of questions the narrator poses. This undermines what at first appears to be a "quest" structure, similar to that of Alastor, Epipsychidion and Prometheus Unbound, replacing it with "something quite different for which we have no name readily available among the familiar props of literary history" (98). We see de Man's aim: to read Shelley's unfinished poem against "historicism," and against attempts to see or to create any sense of "process" or "system" to a literary history of which Shelley might be made a part $(122,123)$. In fact for de Man, "The Triumph" "can be said to reduce all of Shelley's previous work to nought" (120), since it erases any hint of such an attitude to history present in other of Shelley's poems.

This aspect of de Man's reading is important for us because more recently, drawing on the insights and conclusions of "Shelley Disfigured," Joel Faflak has found in "The Triumph" a similar problematizing of the impulse to historicize, this time understood as "a scene of psychoanalysis that unfolds through a series of unanswered questions that stage the (im)possibility of historical understanding" (54). In these terms, the unanswered questions evoke "Freud's interminable procedure" (57), and their presentation as part of a dialogue, between Rousseau and the narrator, "driven by a compulsion to re-member a lost or traumatic past in an indeterminate present, projected hopefully yet fearfully toward a radically uncertain future-is implicitly psychoanalytical" (55). Faflak evidences this by emphasizing a particular moment of circularity in the poem's dialogic structure, when Rousseau asks the narrator to follow him:

["] follow thou, and from spectator turn Actor or victim in this wretchedness

"And what thou wouldst be taught I then may learn 
From thee. (305-08)

For Faflak, this passage illustrates the failure of the poem's "poetic dream" vision. Rousseau is going to impart knowledge to the narrator, who has requested it of him, but in so doing hopes to learn something from the narrator. This indicates Rousseau's faith in historical progress - he expects to learn from the younger man — but also creates a (psychoanalytic) situation in which this faith is deconstructed: "This circular movement back to the future, [analogous to] the cognitive movement of psychoanalysis through its traumatic delays and detours, re-circuits Socratic insight through the vacillations of Lacanian desire, in which the past feeds upon the hope of future enlightenment" (60). Shelley's Rousseau is thus no Socrates, pressing his student on, however painfully, toward greater enlightenment: he reveals how this understanding of progress is problematized by a Lacanian reading of our desire, including desire for such historical (self-) understanding, as a circular and everrenewing, impossible quest for satisfaction, for a truth that always eludes.

As well as referencing de Man, this interpretation draws on Lacan's account of trauma as characterized by repetition of a missed encounter with the "Real," the notoriously elusive concept that forms part of Lacan's Imaginary-Symbolic-Real triumvirate: "an appointment to which we are always called with a real that eludes us" (Concepts 53). This missed encounter "first presented itself in the history of psychoanalysis" in the form of "the trauma" (Concepts 55) that Faflak identifies at work in the cycles and repetitions of "The Triumph of Life." Dreams might provide the key to the trauma and its working through, but they never actually put us in touch with "the first encounter, the real, that lies behind fantasy" (Concepts 54), underlying the structuring of the subject (Lacan uses the German Unterlegen to describe this positioning of the Real). In his seminar on The Ethics of Psychoanalysis, Lacan offered definitions of the grounding of psychoanalysis in tragic ideas and experience, in part by analysing Sophocles' Oedipus, an analysis Linda Belau summarizes in terms of Lacan's idea 
of the traumatic missed encounter: Oedipus "misses the experience," does not realise the nature of his incestuous union with his mother, "which, for him, is the constituting moment of his subjectivity, precisely because he is too present to the experience ... It is precisely this relation to the missed encounter that both tragedy and psychoanalysis expose as the traumatic kernel of subjectivity" (Belau). Lacanian psychoanalysis, like Oedipus, "pursues a traumatic knowledge — an impossible recognition ... something is always left undiscovered", and Sophocles" play performs "the impossibility of a total knowledge": acknowledging this, and conceptualizing it in the elusiveness of the Real, psychoanalysis continually "performs its own failure," giving it a fundamentally “tragic dimension," a decidedly non-idealist aspect (Belau). Lacan's own comments support this:

To make oneself the guarantor of the possibility that a subject will in some way be able to find happiness even in analysis is a form of fraud ... shouldn't the true termination of an analysis ... in the end confront the one who undergoes it with the reality of the human condition? (Ethics 373)

This reality, it seems, is a tragic one. Moreover, it is a tragic reality that Shelley's "Triumph" can seem to support. Converging the related deconstructionist and psychoanalytic approaches just discussed invites us to approach "history," in 'The Triumph' and beyond, as akin to Lacan's Real, famously (and obliquely) defined as "what resists symbolization absolutely"what is always missing and / or missed, in our attempts to know ourselves and the world. If we accept Belau's view of psychoanalysis, which has much support from Lacan himself, we could add that the Real resists symbolization tragically.

In his recent attempt "to conceive of a positive politics of the death drive" (283), Todd McGowan cites one of Lacan's "most important political statements" (6), also from the Ethics seminar, relevant here because it connects together tragedy, the family drama of psychoanalysis in Freud and Lacan, and ideas about moral and political "Good": "The step taken by Freud at the level of the pleasure principle," Lacan writes, "is to show us that there is no Sovereign Good - that the Sovereign Good, which is das Ding, which is the mother, is 
also the object of incest, is a forbidden good, and that there is no other good. Such is the foundation of the moral law as turned on its head by Freud" (Ethics 85). Citing Lacan's reading of Freud as evidence, McGowan argues that "Political theorists of all stripes write to change the world and assist its progression (or its return to a better state), whereas psychoanalysis interprets the world and uncovers the repetition at work where it seems to be progressing" (6), ultimately to uncover the ineluctable operations of the death drive, the "psychic force of repetition and negation," increasingly the focus of the later Freud. This drive "undermines every attempt to construct a utopia" (283), to bring into being any form of new social order, the desire for which is founded on concepts like progress and the good, concepts which psychoanalysis thoroughly problematizes. With respect to Shelley, this returns us to the seeming impasse of de Man's and Faflak's analyses of history in "The Triumph," in which Shelley's failed vision (if that is indeed what the poem contains) confronts us with Faflak's impossible quest for understanding — and also "warns us", in de Man's words, “that nothing, whether deed, word, thought, or text, ever happens in relation, positive or negative, to anything that precedes, follows, or exists elsewhere, but only as a random event whose power, like the power of death, is due to the randomness of its occurrence" (122). The death drive seems to be at work here, in Shelley, and as part of what we have been calling the tragedy of psychoanalysis.

At this point Fredric Jameson's approach to the Lacanian Real, in his essay "Imaginary and Symbolic in Lacan," offers a possible way forward. Jameson presents Lacan's "addition of the Real to a relatively harmless conceptual opposition between Imaginary and Symbolic," as "scandalous to contemporary philosophy," because it allows Lacanian theory the "suborn retention ... of something the sophisticated philosopher was long since supposed to have put between parentheses, namely a conception of the referent." This makes Lacan's concept an affront to the "model-building and language-oriented 
philosophies" Jameson refers to here, since "it is clear that there must be something unacceptable [to such philosophies] about this affirmation of the persistence, behind our representations, of that indestructible nucleus of what Lacan calls the Real"-which, Jameson then tellingly adds, is "simply History itself" (Ideologies 109). This move is an attempt to break out of the repetitious circuits that de Man and Faflak find present in "The Triumph," by aligning Lacan's theory and Marxism as materialisms allied by their shared concerns with forms of end-directed, hermeneutic interpretation and, ultimately, with transformation, of the individual and of the structure of human societies respectively. These readings of "The Triumph," like Jameson's of Lacan, are concerned with an idea of historical progress, of a movement toward an "end" which comprises some new form of understanding, some new knowledge. For de Man, this whole sense of process is illusory, a teleological projection cut off by close analysis of poems like "The Triumph"; for Faflak, it is similarly problematic, revealed by psychoanalysis as a desire to grasp something ungraspable, leaving us to contemplate "a radically uncertain future" (55). For Jameson, it means something different. As the psychoanalyst aims to bring the individual patient, however circuitously, to some new self-understanding, historical materialism seeks to further understand, on the plane of the collective, "the inexorable logic involved in the determinate failure of all the revolutions which have taken place in human history" (Political Unconscious 87) - the utopian goal being to use such understanding eventually to produce a successful one. This is something that Shelley was himself engaged in contemplating, particularly but not only with respect to the French Revolution. It also highlights perennial tensions in Lacanian thought and its possible applications, between a latent "idealism" with respect to language, the pronouncedly non-idealist, "tragic" dimension described by Belau, and an affinity with the avowedly utopian aims of a Marxism like Jameson's, which are each present, in different idioms, in Shelley's writings. I now want to explore this idea further, with reference to Prometheus 
Unbound, to show how we might move our comparisons between Lacan and Shelley in a less tragic direction, contrasting with (and perhaps contradicting) some of the readings above.

\section{Learning about love in Prometheus Unbound}

In the "Lacan" essay, Jameson describes how the first notable synthesis of Marxism and psychoanalysis, by Wilhelm Reich in the 1920s, arose in response to and "addressed the sense that political revolution cannot be fulfilled until the very character structures inherited from the older, prerevolutionary society, and reinforced by its instinctual taboos, have been utterly transformed in their turn" (Ideologies 82). This summary of Reich's perspective could be an effective gloss for two of Shelley's most ambitious poems, Laon and Cythna and Prometheus Unbound. Both of these works and their respective Prefaces address the issue of a transformation in "character," in the minds of the people who will bring the revolution into being, preceding the "political," collective and structural transformation of society. Laon and Cythna is presented to us as "an experiment on the temper of the public mind," which Shelley then qualifies by directing it more toward "the enlightened and refined" (Works 130; my italics) — those among Shelley's contemporaries who might be sympathetic toward the poem's radicalism, without taking it as provocation for a violent revolution of the type which failed in France, because so many of its participants "were incapable of conducting themselves with the wisdom and tranquillity of freemen so soon as some of their fetters were partially loosened" (131). Laon and Cythna has also, however, been fashioned as "a story of human passion in its most universal character", appealing "to the common sympathies of every human breast" (130). From these brief quotations, we get a sense of the importance of this tension in Shelley between his writing as directed toward a small number of individual minds already capable of receiving it as he intends, and the ambition to speak to "every human breast," to participate in effecting a successful revolutionary transformation on a 
collective level, by appealing to and, crucially, educating us in the "common sympathies" we share.

Paul Hamilton has interpreted Shelley's writings as consistently engaged with this tension: the "enlightenment and refinement" of the audience to which Shelley sometimes appeals, "are functions of their poetic sympathy, and so designate membership of that disposable vanguard class that extends through revolutionary thought from Marx to Lenin and Gramsci" (36). Two "analogies of structure" between Marxism and psychoanalysis, observed by Jameson, thus stand out as especially relevant to Shelley: their shared concerns with "the role and risks of the concept of a 'midwife' of truth, whether analyst or vanguard party," and also "the paradox of the end of the revolutionary process, which, like analysis, must surely be considered 'interminable' rather than 'terminable'" (Ideologies 108). In Shelley, the role of the poet and of the poetry he creates is analogous (or very close) to that of Jameson's psychoanalysts and members of the Marxian vanguard class, in their roles as Socratic midwives of truth. His poetry (like Jameson's theory) is deeply concerned with the links between two levels of interpretation and analysis - the interrelated levels of psyche and society, individual and collective. Some of Shelley's poems might even be read as allegories of the relationship between these levels, and thus as explorations of the preconditions necessary for the realization of the types of revolutionary transformations his poetry imagines, and wants to participate in. Shelley's poet and his works, ideally, would bridge the gap between the focus of the analyst (the human mind), and that of the (Marxist) revolutionary (the structure of society). In A Defence of Poetry, Shelley defines such an effect on consciousness as a key function of "Poetry": "The most unfailing companion, and follower of the awakening of a great people to work a beneficial change in opinion or institution, is Poetry" (Works 700-01). The "people" need to be "great" before such a change can take place, and Poetry is vital to this; it not only "follows" such broader historical 
patterns and developments, it affects them by "awakening" the individuals involved to their power to work such a change, on the level of collective attitudes ("opinion"), or of institutions. Of course, the difficulty of finding a way across this chasm between mind and world, in politically effective ways, is exactly what has produced a very extensive Marxistpsychoanalytic literature, much of which can today appear either as wildly utopian (for some readers, for instance, Reich's and Marcuse's work on sexuality and revolution), or as having played out its political hand decades previously. As we see from works like "The Triumph of Life," Shelley is himself alive to and troubled by the difficulty of apprehending such relationships, faced with the sheer intractability of history and the human mind discretely, let alone as they weave intricately with one another. It is certainly a topic that cannot fail to bring us, in the words of Shelley's fragmentary "On Life," to "that verge where words abandon us," as we "look down the dark abyss of-how little we know" (Works 636), into the space, we might say, of the Lacanian Real. Starting from this vertiginous point, I want now to suggest a way in which reading Prometheus Unbound with Lacan, and Jameson, allows us to convert what might be a "tragic" experience of the limits of language and communication, into a more positive, energizing moment of poetic vision — and also brings into focus what problems may arise, in making such an interpretive move.

Let us first consider some of these problems. Some readers, including those generally sympathetic to Shelley's writing, have taken issue with Prometheus Unbound, and particularly with the lyrical visions of Act 4 . We can find, behind some of these issues, tensions in Lacanian thought intersecting with those in Shelley's reworking of Aeschylus' tragic plot, along Platonic lines. Lacan's eighth seminar, Transference, revolves, like Freud's Beyond the Pleasure Principle, around a reading of Plato's Symposium, which Shelley translated in 1818. As Jean-Michel Rabaté points out, recalling Socrates' statement in the dialogue that "Love is the only thing in the world that I understand" (Plato 532), Lacan said 
of his own position as analyst: "I am not there, in the final analysis, for a person's own good, but in order that he love. Does this mean that I must teach him [the patient] how to love? Clearly it seems difficult to avoid this necessity" (Transference 15). Rabaté has suggested that, for Lacan, the Symposium presents "love" as "structured like a metaphor, since it tends to raise some object to the dignity of the precious part or symbol replacing the lacking object of desire" (Socrates is described, metaphorically, by Alcibiades, as possessing such precious parts, the agalmata, inside him). “There is an essential substitution at work here,” Rabaté writes, "and it is often either poetry or theology that can systematize such a substitution" (141). This has certain parallels with the problems some readers have had with Prometheus Unbound, negatively characterizing its final Act itself as a kind of unsatisfactory metaphorical substitution for an object of desire - the revolutionary change it holds out hope for in the real world - and perhaps therefore as poetry that comes uncomfortably close to theology, and / or to some form of philosophical-linguistic idealism. For instance, Hamilton suggests that, "for Prometheus Unbound to convince, there has to be an almost religious confidence in the power to transform individual loss into public good" (50): for Nigel Leask, the "dialogic energy" of the drama is "dispersed," detrimentally, by Act 4 (150); and Gelpi takes issue with this Act's imagining freedom on a cosmic scale, arguing that this "presents nothing like the difficulty involved in imagining a world of harmonious, just, and equable human beings" (263). One of Nancy and Lacoue-Labarthe's main critiques of Lacan is pertinent here. They write that "Lacan tirelessly adapts his discourse, in all sorts of ways, to the possibility of a representation, a true adequate representation of that very thing which challenges and exceeds representation": this creates the "ambiguity in Lacan's work between the daring movement of the invention of a language, of a writing, and the constant desire to found a language of truth - in order to found, on the basis of the latter, a magister and an institution under whose authority a cure could be placed" (xxx). In his challenging, 
defamiliarizing uses of language, allegory and metaphor, especially in what Leask terms the “increasing lyrical abstraction” of Acts 3 and 4 (150), Shelley might be accused of something similar: daringly and inventively seeking what Keach, referring to the Maniac, calls "language that wants to function as sublime emotional music" (90), an impulse which Julian and Maddalo presents as a potential threat or limit to the communication of the poet's ideas, to an audience beyond "the more select classes of poetical readers" (Preface to Prometheus Unbound; Works 232), or perhaps in any politically effective manner. Going further in Nancy and Lacoue-Labarthe's direction, Shelley's most daring poetical moment, his attempt to figure the revolutionary process itself, risks undermining the very radicalism it wants to promote, with its recourse to the only option it (or any other piece of writing, for that matter) has open to it: substituting a metaphor for the thing itself, limited language for real revolution, which resides in the space of Lacan's Real, demanding but always exceeding representation.

Seen in this way, Prometheus Unbound moves precariously between an opening out into the world beyond the poem, ascribing to its readers the responsibility for driving that process forward, and an idealist / theological institution of the authority of its own conception of that process, which it asks us to accept as "truth." Shelley's drama thus takes risks akin to those of Lacanian theory, containing within it similar problems of tragedy and idealism, balancing out its radical potential. This could open up further problems for us, regarding the role of Demogorgon in particular. In terms recalling Everest's and Keach's discussions of the failures of communication in Julian and Maddalo, Hamilton writes that the closing lines of Act 4, spoken by Demogorgon - in which, for example, he implores us in Christ-like language, "To suffer woes which Hope thinks infinite; / To forgive wrongs darker than death or night," and "to hope, till Hope creates / From its own wreck the thing it contemplates" (4.570-74) - highlight a "crisis in communication he has represented throughout Prometheus 
Unbound," and so at least since he first appears in Act 2, if not before. For Hamilton, the problem is that, "Quite how 'hope' keeps its meaning here is baffling. That a transformation rather than an obliteration of its significance awaits it is the poem's great article of faith" (50). Further uncertainties and anxieties that have been raised regarding Demogorgon's function suggest themselves: for instance, Thomas R. Frosch's Lacanian suggestion that "Demogorgon exists in Shelley not only because Shelley senses an otherness in our existence but because Shelley wants there to be a helping power outside us," a helping power which, however, throughout embodies a "potentially destructive energy [which] must be put to creative use" (170). This refers to the links often made by critics between Demogorgon and the idea of "Necessity," first suggested by Mary Shelley's "Note" to Prometheus Unbound, in which she calls him "the Primal Power of the world" (qtd. in Duffy 236 n. 55). Cian Duffy reads this in explicitly political terms, writing that "the dénouement of Shelley's drama is dominated by familiar anxieties about the role of popular violence in effecting political change, about the 'awful' relationship between Necessity and revolution” (150) (Demogorgon is referred to as an "Awful shape" by Jupiter at 3.1.51). Duffy thus suggests that the vision of progress that the drama strives to depict is problematized by Demogorgon's crucial role in it, and by his final voicing of its vision, behind which lurks the possibility that "violent revolutionary retribution may be the 'awful' means by which Necessity will reform the world" (25).

It may seem, therefore, that even the ending of Shelley's most radically optimistic work, with its vision of the role of hope and love in human progress and betterment, is haunted by a power it cannot get on terms with and control, the potentially violent and destructive power of Demogorgon. There is, however, another Lacan-inflected way to approach Prometheus Unbound, which might show Shelley's risks in representing this vision as rewarded. This involves focusing on another key part of Shelley's lyrical drama, and 
indeed one of the interpretive cruxes of Shelley's poetry more generally, Demogorgon's dialogue with Asia in Act 2. This central scene looks forward, in part, to the similar, unanswered question motif developed in "The Triumph of Life," but here this is used by Shelley in a different way. In response to Asia's questionings about Jupiter, Demogorgon refers to the "deep truth," much discussed in Shelley criticism, which is "imageless," which cannot be imaged, or spoken, or sung. The lines are worth quoting at length:

Asia. Who is master of the slave?

Demogorgon. If the abysm

Could vomit forth its secrets: - but a voice

Is wanting, the deep truth is imageless;

For what would it avail to bid thee gaze

On the revolving world? What to bid speak

Fate, Time, Occasion, Chance and Change? To these

All things are subject but eternal Love.

Asia. $\quad$ So much I asked before, and my heart gave

The response thou hast given; and of such truths

Each to itself must be the oracle.

Demogorgon discourages Asia from her impossible wish for a full knowledge of the world (the universe, even) and its processes, Asia's wish for an encounter with what Lacan would call the Real. Crucially, Demogorgon does not insist upon this as an encounter tragically missing and / or missed: he turns Asia away from such questionings, suggesting they are needless, directing her instead to contemplate the role of "eternal Love." Asia then recognizes that she has intuited the nature of this role before: it is a truth already known, inscribed in what the Preface to Julian and Maddalo calls "the text of every heart" (Works 213). It is a truth available, potentially, to all of us, of which Demogorgon is the midwife.

A response to this is crucial for any interpretation of Prometheus Unbound. Further psychoanalytic possibilities of the scene are pointed to by Hamilton, who suggests that, "On a Freudian reading, Demogorgon is the Oedipal structure rather than an Oedipal character: the precondition of the possibility for any ego-formation at all, not a figure in the Greek story" 
(48) that Shelley's lyrical drama reworks. On a Lacanian reading this puts him on terms with "lack": his voiceless and imageless deep truth is what we are always without, opening up an "infinite regress" of questionings, all asked by Asia ("Who is [Jupiter's] master? Is he too a slave?"; "Whom called'st thou God?"; "Who is the master of the slave?") (2.4.109-14), calling to mind de Man's and Faflak's readings of "The Triumph of Life." The tragic dimension of psychoanalysis again begins to assert itself, but in this case is counteracted and transformed, as Shelley's drama as a whole transforms the Aeschylean tragedy of Prometheus' imprisonment into a lyrical vision of his unbinding. Hamilton suggests that "The only escape from this infinite regress is to accept that, like the shapeless Demogorgon"comparable to the "Shape all light" in "The Triumph"_ “" the deep truth is imageless' (2.4.116), and cannot be understood in the way a subject knows or masters an object or individual" (48). The deep truth referred to here is best understood not in the sense of an objective set of conditions, a reality beyond our perception, as in Kant for instance: it is presented, rather, as an immanent process of knowing in which Asia becomes engaged, and in which we are all invited to participate. It cannot be imaged or articulated because, like the Lacanian Real, it exists only in relation to the process that it is itself involved in, as a constituent part. It cannot be grasped, and therefore cannot be "mastered," because, as Demogorgon intimates, no meta- position is available outside of that process. This invocation of the Real carries us also toward Jameson's thought, this time the space of his Political Unconscious, "a space in which History," which we have seen Jameson equate with the Real, "itself becomes the ultimate ground as well as the untranscendable limit of our understanding" (86). In these Jamesonian terms, "History" is "the experience of Necessity" as "the inexorable form of events" (87), a notion Jameson derives by elaborating upon “Althusser's antiteleological formula for history (neither a subject nor a telos), based as it is on Lacan's notion of the Real as 'that which resists symbolization absolutely' and on 
Spinoza's idea of the 'absent cause"” (19-20). "Conceived in this way," Jameson writes, "History is what hurts, it is what refuses desire and sets inexorable limits to individual as well as collective praxis," a History that 'can be apprehended only through its effects, and never directly as some reified force" (88). This suggests, I think, the proper function of Demogorgon, hinting as he does toward the political unconscious — or perhaps, to be more exact, Shelley's politicization of the unconscious - in Prometheus Unbound. The "deep truth" he turns Asia away from might be Lacan's Real, Spinoza's absent cause, Althusser's or Jameson's "History," and this is Shelley's major insight. All of these are names for the ungraspable: that which always elides us, leaving a gap in our knowledge and placing a limit upon our desire, which psychoanalysis has tended to conceive of in the tragic terms we have outlined. Bearing these ideas in mind, I want to make a final suggestion as to how we might use them, to produce a different reading of these key sections of Prometheus Unbound, beginning with some brief reference back to Plato.

Contrasting Shelley's translation of the Symposium and Benjamin Jowett's widely read, Victorian version, Michael O’Neill notes a difference in their renderings of Diotima's account of universal beauty, which is suggestive here. Shelley's version describes how the initiate might learn to 'steadily contemplate' this form, whereas in Jowett's, it is a "vision" that is "revealed" (243). The point of the dialogue between Demogorgon and Asia in Act 2 is precisely that no such vision is revealed to Asia, only the importance of "eternal Love" is pointed toward, intuited, felt rather seen. The dialogue works a change in Asia, which Panthea observes affecting the external world: "Some good change / Is working in the elements which suffer / Thy presence thus unveiled" (2.5.18-20). This unveiling (an image with Platonic resonances), which Panthea gives as evidence that it is not "I alone, / Thy sister, thy companion, thine own chosen one, / But the whole world which seeks thy sympathy" 
(2.5.31-33), leads to another key moment in Asia's steady, gradual realization of the nature of love's role in the drama's revolutionary process:

all love is sweet,

Given or returned. Common as light is love,

And its familiar voice wearies not ever.

Like the wide heaven, the all-sustaining air,

It makes the reptile equal to the God (2.4.40-44)

One of the ambitious goals of Prometheus Unbound is to teach us such a lesson in the importance of this love, by engaging us with it directly_by making us "feel," not "see" it, as Panthea comments of Asia (2.5.17) — in the dialogues through which Asia herself gradually intuits a meaning to Demogorgon's words. The revolutionary process, of which these lessons in love form part, is imagined as never-ending: it relies upon a vision of a utopian goal to sustain its energy and optimism, but must in fact be understood as interminable, like the process of self-understanding that psychoanalysis tries to set in motion. The final Act can also be approached in this way. Shelley offers us no kind of religious revelation: he implicates us in a process, one which may be interminable, but which is driven vitally on by the act of imagining it, as Asia begins to do as she discourses on love. The abysm that Demogorgon refers to in Act 2 might be Shelley's "dark abyss of-how little we know," over the "verge where words abandon us" in "On Life." But this "void abysm" returns in Act 4 as the space, "the deep," into which "Heaven's despotism" and "Conquest" are going to fall, after which "Love from its awful throne of patient power / in the wise heart" is imagined to "spring" into the world (4.554-60). We might think of this ending not as reliant upon a series of dubious metaphorical substitutions, but as the culmination rather of one elaborate metaphor, on the level of the drama's structure, upon which it stakes its success: Prometheus Unbound itself as a bridge spanning the abysm, between the "Love" it wants its reader to be educated in, as a concept, and the actual experience of it in the world — and between the individual psyche that comprehends, and itself depends on such metaphoric substitutions for its very structure 
(according to Lacan), and the greater, collective, revolutionary processes that the drama's metaphors try to figure for us.

This is a particularly hopeful and sympathetic reading of Prometheus Unbound, and one which resists some tendencies in the psychoanalytic thought that has helped us to illuminate some of Shelley's writings. It presents Prometheus Unbound as resistant to the tragic dimension of psychoanalysis, since Shelley's lyrical drama is grounded upon the notion that our lack of ability to grasp the "deep truth," which we have sometimes equated with Lacan's Real, is a potential virtue, instead of or as well as a definitive limitation. Accepting this condition, Shelley suggests, is in fact a method of resistance to the tyranny and desire for mastery represented by Jupiter. This is also a final point upon which Shelley and Lacan might agree rather than diverge. For Yannis Stravrakakis, though Lacan's thought is certainly not "utopian," because "The elimination of lack through a definite symbolisation of the real is impossible," it contains nevertheless a radical potential analogous to Shelley's insight: our inability to grasp the Real, to image or voice Shelley's deep truth, is not necessarily a tragic limitation, it also "is the condition of possibility of our freedom because it means that no order, no matter how repressive it might be, can acquire a stable character" (95). This helps to explain why cultivating "a sympathetic attitude that renounces selfishness or the (pre-Oedipal) idea that the world is at our disposal" (Hamilton 48) is key to Prometheus Unbound. Such selfishness is shown to stem from the impossible desire to master the world absolutely, Jupiter's fantasy of an "omnipotent," stable, undivided self, living in a world "subdued to me" (3.1.3-4), a world of plenitude and absolute power. Whereas, we realise, his identity in fact relies upon that Other, who is Prometheus. Repressive orders and their projects of mastery, allegorized by Jupiter, cannot subdue the resistance of the deep truth / Real, which opens "the cut of dislocation threatening all symbolisations of the social, to the ultimate subversion of any sedimentation of political reality" (Stavrakakis 75). 
Stavrakakis calls this "cut," "The moment of the political" itself, "the moment of contingency and undecidability marking the gap between the dislocation of one socio-political identification and the creation of the desire for a new one" (75). It is such a moment that Shelley dramatizes in Prometheus Unbound, offering, as it does, through its vision of the subversion of Jupiter's order, an allegory of the non-violent defeat of such tyrannical powers. In so doing, it provides us with a dialectical balance to the darker reflections of poems like Julian and Maddalo and "The Triumph of Life," which explore challenging problems that Lacan's theories would later confront, particularly regarding the role of language in the creation of subjectivity, and in communication, especially, for Shelley, of political ideas and ideals. These other poems prefigure certain aspects of the tragic dimension of psychoanalysis, undermining utopian political projects-Prometheus Unbound suggests a way in which this tragedy might be understood differently and so transformed, its problems and contradictions themselves containing a radical potential, waiting to be uncovered by analysis.

\section{References}

Belau, Linda. 'Trauma and the Material Signifier.' Postmodern Culture 11.2 (Jan. 2001): n. pag. Web. 20 Oct. 2017

De Man, Paul. The Rhetoric of Romanticism. New York: Columbia UP, 1984. Print.

Duffy, Cian. Shelley and the Revolutionary Sublime. Cambridge UP, 2005. Print.

Duffy, Edward. Rousseau in England: The Context for Shelley's Critique of the

Enlightenment. Berkeley and Los Angeles, and London: U of California P, 1979.

Print.

Ellmann, Maud. Psychoanalytic Literary Criticism. London and New York: Longman, 1994. Print. 
Everest, Kelvin. “Shelley's Doubles: An Approach to Julian and Maddalo." Shelley's Poetry and Prose. Ed. Donald H. Reiman and Neil Fraistat. New York and London: Norton, 2002: 675-83. Print.

Eyers, Tom. Lacan and the Concept of the Real. Basingstoke and New York: Palgrave Macmillan, 2012. Print.

Faflak, Joel. "The Difficult Education of Shelley's 'The Triumph of Life." Keats-Shelley Journal 58 (2009): 53-78. Print.

Frosch, Thomas R. Shelley and the Romantic Imagination: A Psychological Study. Newark: U of Delaware P, 2007. Print.

Fry, Paul. "Made men: a review article on recent Shelley and Keats studies." Texas Studies in Literature and Language 21 (1979): 433-54. Print.

Gelpi, Barbara Charlesworth. Shelley's Goddess: Maternity, Language, Subjectivity. New York and Oxford: Oxford UP, 1992. Print.

Hamilton, Paul. Percy Bysshe Shelley. Plymouth: Northcote House, 2000. Print.

Hogle, Jerrold. Shelley's Process: Radical Transference and the Development of his Major Works. New York: Oxford UP, 1988. Print.

Jameson, Fredric. The Ideologies of Theory. London and New York: Verso, 2008. Print.

—. The Prison-House of Language. New Jersey: Princeton UP, 1972. Print.

—. The Political Unconscious. Oxford: Routledge, 2002. Print.

Keach, William. Arbitrary Power: Romanticism, Language, Politics. New Jersey: Princeton UP, 2004. Print.

Lacan, Jacques. The Psychoses. Ed. Jacques-Alain Miller. Trans. Russell Grigg. New York and London: Routledge, 1993. Print.

—. Écrits: A Selection. Trans. Bruce Fink, in collaboration with Héloïse Fink and Russell Grigg. New York and London: Norton, 2002. 
- The Four Fundamental Concepts of Psychoanalysis. Ed. Jacques-Alain Miller. Trans.

Alan Sheridan. London: Karnac, 2004. Print.

—. The Ethics of Psychoanalysis. Ed. Jacques Alain Miller. Trans. Dennis Porter. Oxford: Routledge, 2008. Print.

—. Transference. Ed. Jacques Alain Miller. Trans. Bruce Fink. Cambridge: Polity, 2015. Print.

Leask, Nigel. British Romantic Writers and the East. Cambridge: Cambridge UP, 1992. Print. McGowan, Todd. Enjoying What We Don't Have: The Political Project of Psychoanalysis. Lincoln and London: U of Nebraska P, 2013. Print.

Nancy, Jean-Luc and Philippe Lacoue-Labarthe. The Title of the Letter: A Reading of Lacan. Trans. François Raffoul and David Pettigrew. Albany: State U of New York P, 1992. Print.

O’Neill, Michael. "Emulating Plato: Shelley as Translator and Prose Poet.” The Unfamiliar Shelley. Ed. Alan M. Weinberg and Timothy Webb. Farnham: Ashgate, 2009: 239-55. Print.

Plato. The Collected Dialogues. Ed. Edith Hamilton and Huntington Cairns. New Jersey: Princeton UP, Bollingen Series, 1963. Print.

Rabaté, Jean-Michel. Jacques Lacan. Basingstoke: Palgrave, 2001. Print.

Ragland-Sullivan, Ellie. Jacques Lacan and the Philosophy of Psychoanalysis. London: Croom Helm, 1986. Print.

Rousseau, Jean-Jacques. The Basic Political Writings. Trans. and ed. Donald A. Cress. 2nd ed. Indianapolis: Hackett, 2011. Print.

Shelley, Percy Bysshe. Percy Bysshe Shelley. The Major Works. Ed. Zachary Leader and Michael O’Neill. Oxford: Oxford UP, 2003. Print. 
Stravrakakis, Yannis. Lacan and the Political. London and New York: Routledge, 1999. Print.

Weisman, Karen A. Review of Monika Lee. Rousseau's Impact on Shelley: Figuring the Written Self. New York: Edward Mellen, 1999. University of Toronto Quarterly 70.1 (Winter 2000 / 2001): 412-13. Print. 